\title{
Genetic merit for fertility traits in Holstein cows: I. Production characteristics and reproductive efficiency in a pasture-based system
}

\author{
S. B. Cummins, ${ }^{\star} †$ P. Lonergan, $\dagger$ A. C. O. Evans, † D. P. Berry, ${ }^{\star}$ R. D. Evans, $\neq$ and S. T. Butler ${ }^{\star 1}$ \\ ${ }^{*}$ Animal and Grassland Research and Innovation Centre, Teagasc, Moorepark, Fermoy, Co. Cork, Ireland \\ †School of Agriculture, Food Science and Veterinary Medicine, University College Dublin, Belfield, Dublin 4, Ireland \\ łlrish Cattle Breeding Federation, Bandon, Co. Cork, Ireland
}

\section{ABSTRACT}

The objective of the present study was to characterize the phenotypic performance of cows with similar proportions of Holstein genetics, similar genetic merit for milk production traits, but with good (Fert+) or poor (Fert-) genetic merit for fertility traits. Specifically, we tested the hypothesis that cows with a negative estimated breeding value for calving interval would have superior fertility performance and would have detectable differences in body reserve mobilization and circulating concentrations of metabolic hormones and metabolites compared with cows that had a positive estimated breeding value for calving interval. For the duration of the study, cows were managed identically as a single herd in a typical grass-based, spring-calving production system. A total of 80 lactation records were available from 26 Fert+ and 26 Fert- cows over 2 consecutive years (2008 and 2009). During yr 1, cows were monitored during a 20-wk breeding season to evaluate reproductive performance. Milk production, body condition score (scale 1 to 5), body weight, grass dry matter intake, energy balance, and metabolic hormone and metabolite data were collected during both years. The Fert+ cows had greater daily milk yield (19.5 vs. $18.7 \mathrm{~kg} / \mathrm{d}$ ), shorter interval from calving to conception (85.6 vs. $113.8 \mathrm{~d}$ ), and fewer services per cow (1.78 vs. $2.83)$. No difference between groups in grass dry matter intake, energy balance, or body weight was observed. The Fert+ cows maintained greater BCS during mid (2.84 vs. 2.74 units) and late lactation (2.82 vs. 2.73 units). Circulating concentrations of insulin-like growth factor-I were greater throughout the gestation-lactation cycle in Fert+ cows (148.3 vs. $128.2 \mathrm{ng} / \mathrm{mL}$ ). The Fert+ cows also had greater circulating concentrations of insulin during the first $4 \mathrm{wk}$ of lactation (1.71 vs. 1.24 $\mu \mathrm{IU} / \mathrm{mL})$. Analysis of records from national herd data verified the association between genetic merit for fertility traits and phenotypic reproductive performance;

Received July 19, 2011.

Accepted November 2, 2011.

${ }^{1}$ Corresponding author: stephen.butler@teagasc.ie
Fert + cows $(\mathrm{n}=2,436)$ required $11.1 \mathrm{~d}$ less to recalve than did Fert- cows $(n=1,388)$, and the percentage of cows that successfully calved for the second time within 365 and $400 \mathrm{~d}$ of the first calving was 8 and $13 \%$ greater for Fert+ compared with Fert- cows, respectively. These results demonstrate that genetic merit for fertility traits had a pronounced effect on reproductive efficiency, BCS profiles, and circulating concentrations of insulin-like growth factor-I.

Key words: genetic selection, fertility trait, reproduction, insulin-like growth factor-I

\section{INTRODUCTION}

The efficiency of pasture-based milk production systems is based on maximizing milk production from low-cost grazed grass (McCarthy et al., 2007). The success of these systems is largely dependent on achieving a compact calving pattern to coincide with the start of the grass growing season. The maintenance of this compact calving pattern is reliant on the cow's ability to successfully calve, complete uterine involution, return to cyclicity, exhibit estrus, conceive, and maintain a pregnancy in a window of $85 \mathrm{~d}$, thus maintaining a 365-d calving interval. The relative importance of female fertility is markedly greater in seasonal calving systems than in year-round calving systems (Veerkamp et al., 2002). Failure to maintain the target calving interval of $365 \mathrm{~d}$ in a seasonal calving system results in financial losses at farm level (Evans et al., 2006b). This arises through decreased volumes of saleable milk and increased voluntary and involuntary culling rates and breeding costs (Plaizier et al., 1997).

Despite the crucial role fertility plays in maximizing economic output, reproductive efficiency in dairy cows has decreased during the past half century both in Ireland (Evans et al., 2006a) and internationally (Royal et al., 2000; Washburn et al., 2002). In Ireland, some of this decrease has been attributed to the intense selection for milk production traits and the associated introgression of North American Holstein genes (Horan et al., 2004). An extensive study of performance indicators on 14 spring-calving dairy farms between 1990 and 
2001 in Ireland confirmed these trends (Evans et al., 2006a). During this 11-yr period, the pedigree index for milk volume increased by $25 \mathrm{~kg}$ per year, the proportion of Holstein genes increased from 8 to $63 \%$, and the calving rate to first service decreased from $55 \%$ in 1990 to $44 \%$ in 2001.

To address the problem of decreasing fertility, the Irish national breeding program shifted from being predominantly focused on milk production traits to a more holistic multi-trait index called the Economic Breeding Index (EBI; Veerkamp et al., 2002). Introduced in 2001, the EBI included production and nonproduction traits, thus identifying animals of superior genetic merit for delivering on-farm profit (Berry et al., 2007). Since its introduction, the EBI has evolved to include 6 subindexes (relative emphasis in parenthesis); milk production (38.1\%), fertility and survival (34.8\%), calving performance $(10.3 \%)$, beef carcass $(7.2 \%)$, maintenance (6.1\%), and health (3.6\%; http://www.icbf.com). The fertility subindex comprises 2 traits: calving interval $(23.2 \%)$ and survival $(11.5 \%)$. Good genetic merit for fertility traits requires negative EBV for calving interval and positive EBV for survival.

Previous studies evaluating the effects of genetic influences on reproductive efficiency have compared animals of varying genetic merit for milk production (Buckley et al., 2000) or varying Holstein ancestry (Horan et al., 2004). In both cases, large differences in reproductive performance were reported. The precise mechanisms responsible for fertility differences remain poorly understood. In previous studies comparing models of good and poor fertility, observed differences in phenotypic fertility performance were generally confounded with genetic merit for milk yield and phenotypic milk production. Therefore, the aim of this study was to characterize the phenotypic performance of cows with similar genetic merit for milk production traits and similar proportions of Holstein genes, but divergent genetic merit for fertility traits (genotypes Fert+ and Fert-). Specifically, we tested the hypothesis that cows with negative EBV for calving interval would have superior fertility performance, would be less reliant on body reserve mobilization, and would have detectable differences in circulating concentrations of metabolic hormones and metabolites compared with cows that had positive EBV for calving interval.

\section{MATERIALS AND METHODS}

\section{Herd Establishment}

Using the autumn 2007 official dairy evaluation published by the Irish Cattle Breeding Federation (ICBF, Bandon, Co. Cork, Ireland), the national dairy cattle database was screened for heifers due to calve for the first time in Spring 2008. Restrictions were placed on the EBV for milk production (between +200 and $+900 \mathrm{~kg}$ ) and proportion of Holstein genetics (>75\%). Within this population, heifers with extreme positive (i.e., poor fertility) and negative (i.e., good fertility) EBV for calving interval were identified. Poor-fertility (Fert-) heifers were restricted to animals where both the sire and maternal grand-sire had positive EBV for calving interval. Conversely, good-fertility (Fert+) heifers were restricted to animals where both the sire and maternal grand sire had negative EBV for calving interval. Heifers identified as being available for purchase were screened for infectious diseases. A total of 18 nulliparous Fert- and 18 nulliparous Fert+ cows passed the Moorepark Biosecurity Protocol and were purchased and moved in January 2008 to the Moorepark Animal \& Grassland Research and Innovation Centre in Fermoy, Co. Cork, Ireland $\left(55^{\circ} 10^{\prime} \mathrm{N} 8^{\circ} 16^{\prime} \mathrm{W}\right)$.

The process of selection described above was repeated with the same criteria (as explained above) during autumn 2008 and an additional 8 nulliparous Fert- and 8 nulliparous Fert+ heifers were purchased. The EBV of the 2 genotypes are summarized in Table 1. Within the Irish national herd, these animals were representative of the top quartile in genetic merit for milk production, whereas the Fert+ and Fert- groups represented the top $20 \%$ and bottom $5 \%$ for calving interval, respectively.

\section{Feed and Management System}

Animals were managed identically as 1 herd in a typical grass-based, spring-calving production system. Following parturition, cows were turned out to grass in early February until mid-November and grazed under a rotational grazing system, as described by Dillon et al. (1995), in a predominantly perennial ryegrass (Lolium perenne L.) sward. Fresh pasture was allocated daily to the herd following morning milking using temporary fencing. During yr 1, the mean daily herbage allowance of $13 \pm 1.45 \mathrm{~kg}$ of $\mathrm{DM} / \mathrm{cow}$ per day was supplemented with $3.9 \pm 1.21 \mathrm{~kg}$ of $\mathrm{DM} /$ cow per day of concentrate. Similarly during yr 2, the mean daily herbage allowance of $14.3 \pm 1.29 \mathrm{~kg}$ of $\mathrm{DM} /$ cow per day was supplemented with $4.0 \pm 1.69 \mathrm{~kg}$ of $\mathrm{DM} / \mathrm{cow}$ per day. The mean pregrazing herbage yield was $1,337 \pm 494 \mathrm{~kg}$ of DM/ha in yr 1 and 1,146 $\pm 396 \mathrm{~kg}$ of DM/ha in yr 2 . Cows were dried off $80 \mathrm{~d}$ before expected calving date, housed in a freestall barn and given full time access to a TMR of grass silage (90\%) and concentrate $(10 \%)$.

\section{Animal Measurements}

Cows were milked twice daily at 0730 and $1630 \mathrm{~h}$. Milk yield was recorded at each milking using electronic 
Table 1. The mean estimated breeding value ${ }^{1}$ (and SD) for the 2 groups of Holstein cows studied based on their milk production, individual calving interval, sire calving interval, and maternal grandsire calving interval

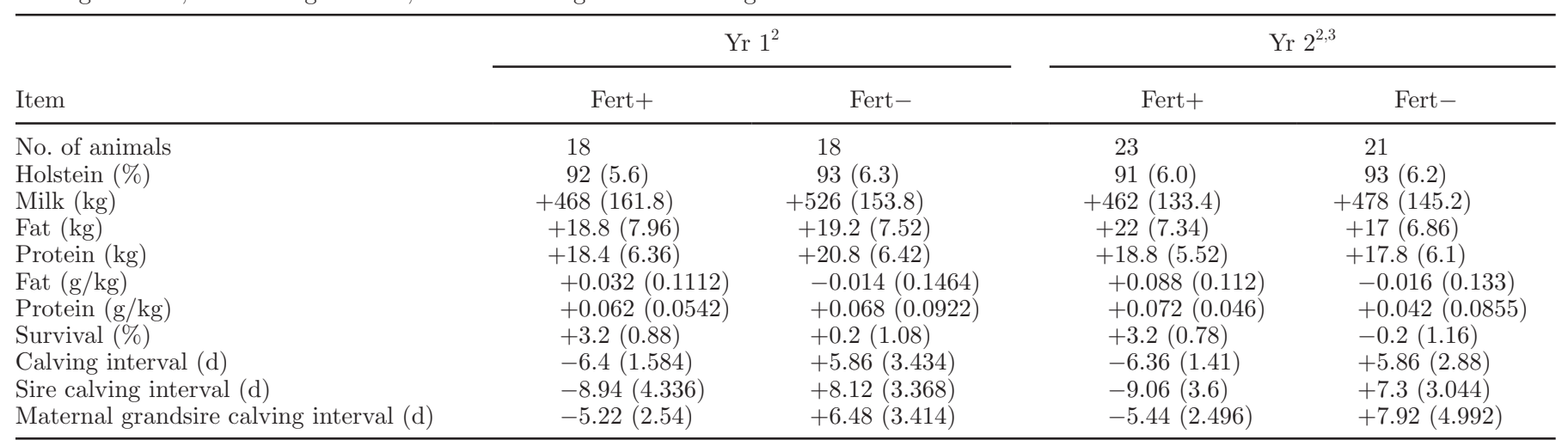

${ }^{1}$ All PTA were obtained from autumn 2008 and autumn 2007 official dairy evaluations published by the Irish Cattle Breeding Federation and multiplied by 2 to convert to EBV.

${ }^{2}$ Fert $+=$ good-fertility cows; Fert $-=$ poor-fertility cows.

${ }^{3}$ In yr 2, the Fert+ group comprised 15 second- and 8 first-parity cows, and the Fert- group comprised 13 second- and 8 first-parity cows.

milk meters (Dairymaster, Causeway, Co. Kerry, Ireland). Milk composition (fat, protein, and lactose) was determined weekly from successive evening and morning samples by mid-infrared reflectance spectroscopy using a FT6000 MilkoScan instrument (DK-3400; Foss Electric, Hillerød, Denmark). Cow BW was measured weekly and BCS (Edmonson et al., 1989) was assessed every 2 to 3 wk throughout the study. During lactation, BW and BCS measurements were taken immediately after morning milking by a single operator. Individual animal grass DMI (GDMI) measurements were carried out on 3 occasions during yr 1 at wk 13, 28, and 35 postpartum ( $\mathrm{SD} \pm 3.2 \mathrm{wk}$ for all time points) and on 1 occasion in yr 2 , at wk 13 postpartum $(\mathrm{SD} \pm 3.9 \mathrm{wk})$ using the n-alkane technique (Mayes et al., 1986) as modified by Dillon and Stakelum (1989). Supplemental concentrate fed at the time of GDMI measurements was added to the GDMI figure to calculate total DMI (TDMI). Energy balance (EB) was estimated as the difference between energy intake and the sum of the energy required for maintenance and milk production. The French net energy (NE) system was used, where 1 unité fourragère lait (UFL) is the NE content of $1 \mathrm{~kg}$ of air-dried barley for milk production (Vermorel, 1989).

\section{Blood Sampling and Laboratory Analysis}

In yr 1 , blood samples were collected once every $2 \mathrm{wk}$ throughout lactation. In yr 2, blood samples were collected weekly for $3 \mathrm{wk}$ before parturition, twice weekly during the first $4 \mathrm{wk}$ of lactation, once weekly from wk 5 to 9 , and once every 2 wk thereafter until the end of lactation. Sampling took place after morning milking and before returning to fresh pasture. Blood samples were collected via coccygeal venipuncture into
Vacutainers containing lithium heparin as an anticoagulant (Becton Dickinson, Plymouth, UK). Samples were placed in a centrifuge for $15 \mathrm{~min}$ at $2,000 \times \mathrm{g}$, plasma was decanted, and stored at $-20^{\circ} \mathrm{C}$ until further analysis. Blood plasma was analyzed for the metabolites NEFA, BHBA, and glucose concentrations by enzymatic colorimetry (NEFA kit supplied by Wako Chemicals GmbH, Neuss, Germany; BHBA and glucose kits supplied by ABX Mira, Montpellier, France). Plasma insulin concentrations were determined using a solid-phase fluoro-immunoassay (AutoDELFIA; PerkinElmer Life and Analytical Sciences, Turku, Finland), with appropriate kits (Unitech BD Ltd., Dublin, Ireland). Inter- and intra-assay coefficients of variation were 17.5 and $8.5 \%$, respectively. Circulating IGF-I concentrations were quantified using a validated double antibody RIA, following ethanol:acetone:acetic acid extraction as described by Enright et al. (1989). Inter- and intra-assay coefficients of variation were 15.6 and $15.8 \%$ respectively. For all hormone assays, each genotype was equally represented in each assay and all samples for a cow of a given genotype were completed in a single assay.

\section{Reproductive Management}

The reproductive performance of the herd was monitored in yr 1 during a 20 -wk breeding season with a mating start date of April 14. Before the mating start date, all cows greater than 30 DIM were examined using transrectal ultrasonography $(7.5-\mathrm{MHz}$ transrectal transducer, Aloka SSD-900; Aloka Ltd., Tokyo, Japan) to determine utero-ovarian status. One cow from each genotype was diagnosed with endometritis, and were treated with an i.m. $\mathrm{PGF}_{2 \alpha}$ injection containing 25 
mg dinoprost tromethamine (Lutalyse; Pfizer Ireland, Dublin, Ireland), followed by intrauterine cephapirin (Metricure; Intervet International BV, Boxmeer, the Netherlands) 2 to $4 \mathrm{~d}$ later after observation of estrus. During the breeding season, heat detection was carried out a minimum of 3 times daily with the aid of tail paint. Cows detected in heat were inseminated with frozen-thawed semen from sires of their own genetic group to generate replacement heifers. For each sire used, semen was from a single ejaculate, and sperm viability and quality was verified before use in the experiment. All inseminations were carried out by a single AI technician during the breeding season. Pregnancy diagnosis was carried out by transrectal ultrasound at 30 to $36 \mathrm{~d}$ and again at 60 to $66 \mathrm{~d}$ post-insemination to measure the rate of late embryo loss. Final pregnancy status was determined by transrectal ultrasound $80 \mathrm{~d}$ after the completion of the breeding season. In yr 2 , breeding was delayed to allow collection of biological samples of interest and, hence, no fertility performance indicators were available.

\section{Data Handling}

All data handling was carried out using SAS (SAS Institute Inc., Cary, NC). Data were checked for normality. A Box-Cox transformation was used to normalize the distribution of IGF-I, insulin, NEFA, and BHB data. Linear interpolation was used to calculate values for every day of the study for blood metabolites, hormones, and BCS, and the estimated daily values were collapsed into weekly means. Circulating concentrations of blood metabolites, metabolic hormones, and BCS data for each cow were analyzed over the full gestationlactation cycle [from wk -3 ( -6 for BCS) to wk 42]. These data were also divided into 4 time periods [dry period: from wk -3 ( -6 for BCS) to wk 0 prepartum; early lactation: from wk 1 to 12 postpartum; midlactation: from wk 13 to 28 postpartum; and late lactation: from wk 29 to 42 postpartum]. Additionally, separate analysis was carried out on blood metabolite and hormone concentration data during wk 1 to 4 of lactation. The week of BCS nadir was determined by identifying the earliest postpartum occurrence of the lowest BCS value recorded during the first 15 wk of lactation.

\section{Study Replicated Using National Herd Data}

Data from the Irish national herd were also used to determine whether results from the Fert+/Fert- herd were consistent with on-farm performance records from cows of similar genetic merit. Data on first-parity Holstein dairy cows calving between the years 2006 and 2010 inclusive $(\mathrm{n}=501,922)$ were extracted from the
Irish Cattle Breeding Federation database. Herds that were predominantly spring calving, where $80 \%$ of cows calved between January 1 and July 31, were retained. Herds with less than 5 cows in any year were removed for that year. Only cows from a known AI sire and AI maternal grand sire $(\mathrm{n}=185,354)$ were retained. The pedigree index for each cow was calculated as $0.5 \times$ sire $\mathrm{EBV}+0.25 \times$ maternal grandsire EBV. To avoid any environmental covariance between cow phenotypic performance and cow pedigree index, the preceding year's official dairy evaluations published by the Irish Cattle Breeding Federation were used to estimate cow pedigree index. Restrictions were placed on cow EBV for milk production (between +256 and $+514 \mathrm{~kg}$ ), calving interval (Fert+: sire $<-3.5$, maternal grandsire $<-3.5$; Fert-: sire $>3.5$, maternal grandsire $>2$ ) and proportion of Holstein genes $(>71 \%)$ in line with the selection criteria set out for the Fert+ and Fert- cows used in the controlled study. A total of 2,371 Fert- and 4,859 Fert+ first-lactation cows in 2,560 herds were available for inclusion in the analysis. The number of cow records available for each of the 5 yr (2006-2010) were 460, $978,1,198,1,801$, and 2,793, respectively. An additional 79,408 first-parity herdmates of these animals were included in the analysis for improved estimation of fixed effects, especially contemporary group effects.

Standardized 305-d milk, fat, and protein yields were estimated by area under the curve from d 0 to 305 (Olori and Galesloot, 1999). Milk fat and protein percent was calculated by dividing fat and protein yields by milk yield. The fat-to-protein ratio was calculated by dividing fat yield by protein yield. Calving interval was defined as the number of days from the date of first calving to the date of second calving. Animals that failed to recalve or had calving intervals outside the range of 300 to $800 \mathrm{~d}$ were removed from the analysis of fertility variables. Two separate traits were used to describe the survival of an animal to its second lactation: recalving within $365 \mathrm{~d}$ of first calving (the target for a seasonal calving system) and recalving within 400 $\mathrm{d}$ of first calving (a minimum target for a seasonal calving system).

An algorithm was used to generate contemporary groups for herd-year-season at first calving for milk production and calving interval data separately. The algorithm initially grouped first-parity animals within herd that had a calving date within $10 \mathrm{~d}$ of each other. If the number of records within any contemporary group was less than 7 , they were combined with the next contemporary group, if the start date of one contemporary group and the end date of the other contemporary group was $<182 \mathrm{~d}$. Only contemporary groups with a minimum of 5 animals were retained. A total of 86,638 animals in 4,290 contemporary groups 
remained for inclusion in analysis of milk production data, whereas 49,661 animals in 3,572 contemporary groups remained for inclusion in the analysis of calving interval and survival.

\section{Statistical Analyses}

Experimental Herd Data. All statistical analyses were carried out using SAS (SAS Institute Inc.). The effect of genotype on variables with repeated measures, such as weekly production variables (milk yield, milk fat, protein and lactose concentrations, BCS, and BW), GDMI, TDMI, EB variables (yr 1), and blood metabolite and hormone concentrations were determined using mixed models with cow nested within genotype as a random effect. A first-order autoregressive covariance structure with homogeneous variances among weekly records within cow-parity provided the best fit to the data. Transformed data (IGF-I, insulin, NEFA, and BHBA) were used to calculate $P$-values, and the estimated group means and 95\% confidence intervals were derived from back-transformed values. The effect of genotype, parity, calving date, year, lactation week, and their interactions were included in the final model where significant $(P<0.1)$. Where an interaction existed between genotype and parity, orthogonal contrasts were used to compare differences between genotypes within parity.

The effect of genotype on continuous variables without repeated measures such as number of services, calving to first service interval (all cows were served at least once), calving-to-conception interval, GDMI, TDMI, and $\mathrm{EB}$ variables (yr 2), and selected BCS variables (i.e., BCS at calving, postpartum BCS nadir, week of BCS nadir, and changes in BCS from parturition to nadir and from nadir to end of lactation) were determined using the mixed model with cow nested within genotype as a random effect. The effect of genotype, parity, and the interaction between genotype and parity were tested, calving date and year were included as adjustment variables, and significant effects $(P<0.1)$ were maintained in the final model.

Differences between genotypes for variables with a binomial distribution (conception rate to first service, pregnancy rate to first and second service, submission rate, 42-d pregnancy rate, embryo mortality, and overall pregnancy rates) were tested using the Fisher exact test. The interval from mating start date to conception was used to calculate a Kaplan-Meier estimate of survival function. Log-rank tests were used to compare the resulting survival analysis curves. For illustrative purposes, the proportion of cows pregnant was extrapolated from the survival distribution function for each genotype.
A Wilmink (Wilmink, 1987) exponential model curve was fitted to daily milk yield to generate lactation profiles for each lactation. The Wilmink function is described by the equation $y_{t}=a+b e^{-0.05 t}+c t$. In this model, $y_{t}$ represents daily milk yield at day $t$ of lactation. The $a$ parameter represents the height of the curve and a negative $b$ value and $c$ value represent the rate of increase of daily milk yield during the initial lactation stage and the rate of decline from peak, respectively. Regression parameters were estimated separately for each cow-parity. Residuals of predicted daily milk yield were then calculated as the difference between the predicted and the actual at each day of lactation. The mean square prediction error was calculated as the standard deviation of the calculated residuals.

National Herd Data. Fixed effects linear models were used to quantify the association between genotype and milk production and fertility variables. Herd-yearseason contemporary group, proportion of Holstein genes, and age at first calving were included as fixed effects in the model where significant $(P<0.1)$. The association between genetic merit and recalving within $365 \mathrm{~d}$ of first calving and recalving within $400 \mathrm{~d}$ of first calving was determined using generalized linear mixed models; herd-year-season, age at first calving, and proportion of Holstein genes were included as adjustment variables, where significant $(P<0.1)$.

\section{RESULTS}

\section{Milk Production}

Mean daily milk production and the parameters for the Wilmink exponential function are summarized in Table 2. During the full lactation, genotype had a significant effect $(P<0.05)$ on milk yield, with Fert+ cows having greater milk yield $(19.5 \pm 0.02 \mathrm{~kg} / \mathrm{d})$ than Fert- cows $(18.7 \pm 0.02 \mathrm{~kg} / \mathrm{d})$. Milk solids yield tended to be greater $(P=0.09)$ in Fert+ cows (Figure 1). Mean milk fat and lactose concentrations did not differ (both $P>0.05$ ) between the Fert+ and Fert- cows, but Fert- cows tended to have greater milk protein concentration $(P=0.07)$.

The Wilmink function fit the daily milk yield data well, with a median coefficient of determination value of 0.72 . The Fert+ cows tended to have a higher $(P$ $=0.08$ ) lactation curve (a parameter) compared with Fert- cows (Figure 1). No effect of genotype or genotype by parity interaction was observed for either the rate of increase to peak milk yield (b parameter), or the rate of decline from peak milk yield (c parameter). Days postcalving when peak daily milk yield occurred did not differ between genotypes (31.9 and $29.0 \mathrm{~d}$ for the Fert+ and Fert- cows, respectively). 
Table 2. The effect of genetic merit for fertility traits on mean daily milk production performance over the complete lactation

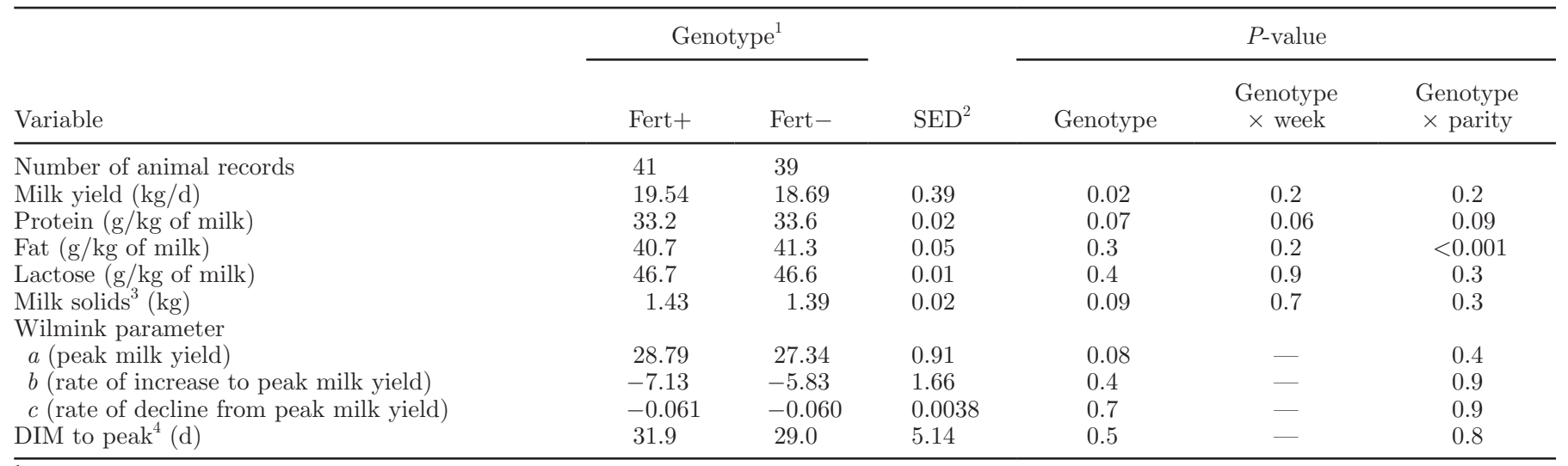

${ }^{1}$ Fert+ = good-fertility cows; Fert- = poor-fertility cows.

${ }^{2} \mathrm{SED}=$ pooled standard error of the difference.

${ }^{3}$ Combined yield of fat and protein.

${ }^{4}$ The day when the Wilmink parameter $a$ was estimated.

\section{Reproduction and Fertility}

The reproductive performance of the herd was monitored during yr 1 of the study on 36 first-parity cows. The calving period ranged from January 8 to April 14, with the median calving date being February 2 and 9, for the Fert- and Fert+ groups, respectively. The effect of genotype on reproductive performance is summarized in Table 3. No effect of genotype on interval from calving to first service or $21 \mathrm{~d}$ submission rate was observed, but the interval from calving to conception was significantly shorter $(P<0.05)$ for Fert+ $(85.6$ \pm 7.0 d) compared with Fert- $(113.8 \pm 7.8$ d $)$ cows. Pregnancy rate to first and second service and the 6 wk in-calf rate tended to be greater $(P=0.08$ and $P$ $=0.09$, respectively) for the Fert + cows. The number of services per cow was fewer $(P<0.05)$ for the Fert+ compared with the Fert- cows over the course of the breeding season. The proportion of cows establishing pregnancy during the course of the breeding season is illustrated in Figure 2, and indicates the difference between genotypes in the interval from mating start date to successful pregnancy establishment (effect of genotype, $P<0.05)$.

\section{Energy Balance, DMI, BCS, and BW}

No difference between Fert+ and Fert- cows was observed for GDMI (12.4 and $12.1 \mathrm{~kg} / \mathrm{d}$, respectively) or TDMI (15.4 and $15.1 \mathrm{~kg} / \mathrm{d}$, respectively) across the 3 measurement time points in yr 1 . In addition, no effect of genotype was observed on mean daily EB at the DMI measurement time points $(2.87 \pm 0.23$ vs. 3.09 $\pm 0.23 \mathrm{UFL} / \mathrm{d}$, Fert+ and Fert-, respectively). Parity had a significant effect $(P<0.001)$ on GDMI in yr
2, being greater in parity $2(17.5 \pm 0.39 \mathrm{~kg} / \mathrm{d})$ than parity $1(12.5 \pm 0.24 \mathrm{~kg} / \mathrm{d})$ cows. No effect of genotype or genotype by parity interaction was observed for EB or GDMI at the single measurement time point in $\mathrm{yr}$ 2 . The BCS and BW profiles of both genotypes are illustrated in Figure 3. No differences between genotypes were observed for BW, but Fert+ cows had greater BCS during early $(+0.13$ units, $P=0.06)$, mid $(+0.1$ units, $P<0.05)$, and late $(+0.09$ units, $P<0.05)$ lactation compared with Fert- cows (Table 4). A significant genotype by week interaction for BCS occurred during the gestation-lactation cycle and early lactation time periods. The difference between genotypes was greatest in first-parity cows at calving and during early lactation (both $P<0.05$ ). The Fert+ cows tended to have greater $(P=0.07)$ BCS at nadir, but no differences were observed for week of lactation at nadir, or changes in BCS from parturition to nadir and from nadir to end of lactation.

\section{Circulating Concentrations of Blood Metabolites and Metabolic Hormones}

No differences between genotypes were observed during the dry period (all $P>0.05$ ) for plasma concentrations of metabolites (Table 5). A significant genotype by parity interaction was observed for plasma NEFA concentration $(P<0.05)$ during early lactation; firstparity Fert+ cows had greater circulating concentrations compared with first-parity Fert- cows, but no differences were observed in second-parity cows. Genotype had no effect $(P>0.05)$ on circulating concentrations of NEFA or glucose during the gestation-lactation cycle. During early lactation, Fert+ cows had a greater $(P<0.01)$ mean circulating concentration of BHBA 

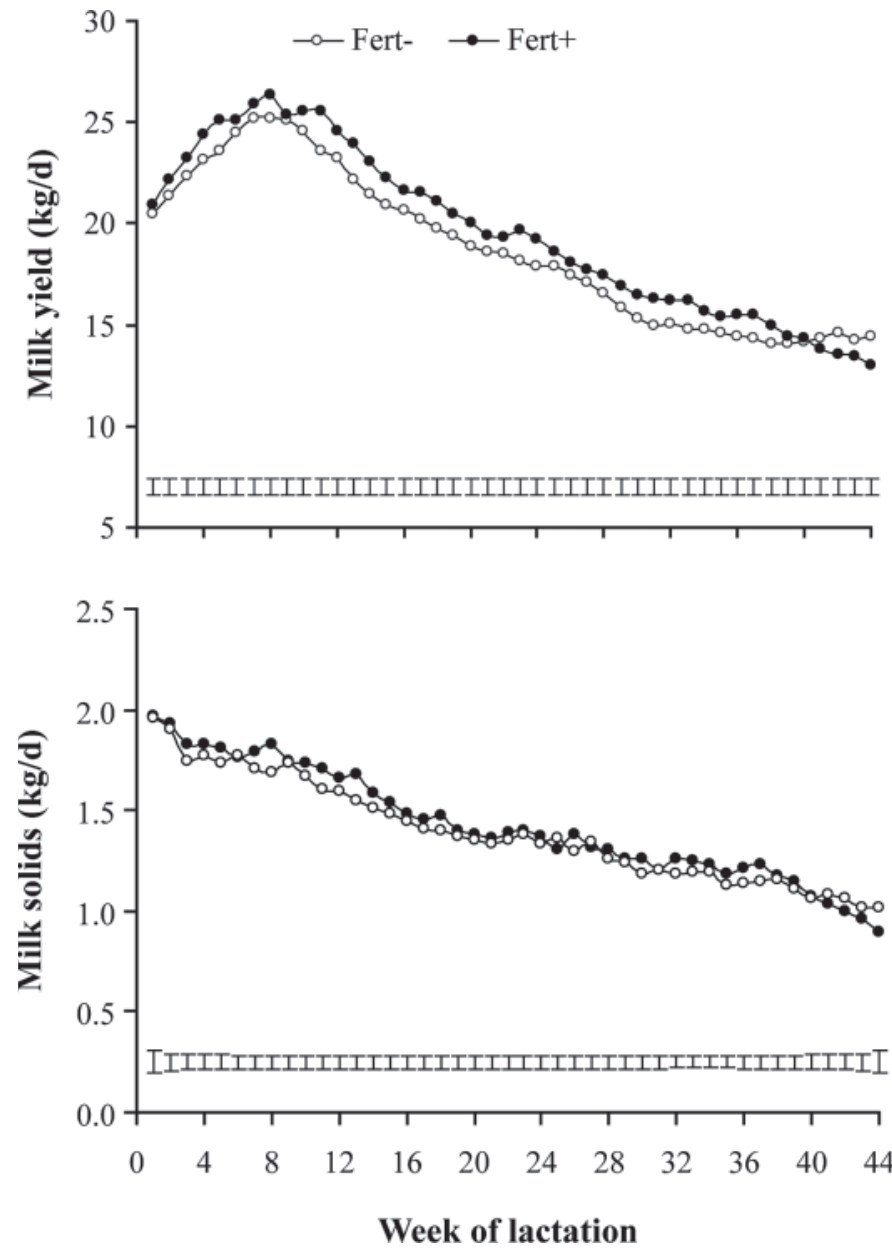

Figure 1. The mean daily milk yield and milk solids yield profiles of the good-fertility (Fert+) and poor-fertility (Fert-) cows during the full lactation. Vertical bars indicate the pooled standard error of the difference (SED). Top panel: mean daily milk yield was greater $(P<$ $0.05)$ in Fert + cows $(\mathrm{SED}=0.39 \mathrm{~kg} / \mathrm{d})$ than in Fert - cows. No genotype $\times$ week or genotype $\times$ parity effects were detected. Bottom panel: Mean milk solids yield tended to be greater $(P=0.094)$ in Fert+ cows $(\mathrm{SED}=0.02)$, whereas no effect of genotype $\times$ week or genotype $\times$ parity interaction was observed.

compared with Fert- cows (0.340 vs. $0.276 \mathrm{mmol} / \mathrm{L}$, respectively), but no differences were detected during mid or late lactation. The effect of genotype on mean plasma concentrations of IGF-I and insulin during the gestation-lactation cycle are illustrated in Figure 4. The Fert + cows had greater $(P<0.01)$ mean circulating concentrations of IGF-I throughout the study period compared with Fert- cows. No overall effect of genotype was observed on mean circulating concentrations of plasma insulin during the gestation-lactation cycle $(P>0.05)$; however, mean plasma insulin concentrations were greater $(P<0.05)$ in Fert+ $(1.71 \mu \mathrm{IU} / \mathrm{mL})$ than in Fert- cows $(1.24 \mu \mathrm{IU} / \mathrm{mL})$ during the first 4 wk of lactation.

\section{Analysis of National Herd Data}

Performance of first-parity cows from the Irish national herd $(\mathrm{n}=7,230)$ that fit the selection criteria of the Fert+/Fert- herd are summarized in Table 6. A significant $(P<0.01)$ association was observed between genotype and 305-d milk yield, with Fert+ cows having greater milk yield $(5,556 \pm 11.0 \mathrm{~kg})$ than did Fertcows $(5,503 \pm 15.9 \mathrm{~kg})$. No differences $(P>0.05)$ were observed between genotypes for 305-d protein or fat yield, but Fert- cows had greater mean milk fat $(P<$ $0.05)$ and protein $(P<0.001)$ concentration than did Fert+ cows. Fert + cows took $11.1 \mathrm{~d}$ less $(P<0.001)$ to recalve than did Fert- cows. The proportion of cows that re-calved within $365 \mathrm{~d}(+8 \%)$ and within $400 \mathrm{~d}$ $(+13 \%)$ were greater for Fert+ compared with Fertcows $(P<0.001)$.

\section{DISCUSSION}

This study clearly indicates that genetic merit for fertility traits has a profound effect on phenotypic fertility performance. Other factors that are known to affect fertility performance were similar for both groups (herd management, plane of nutrition, proportion of Holstein genes, and genetic merit for milk production traits). Furthermore, production and fertility data for Fert+ and Fert- cows obtained from the Irish national herd database substantiated the findings from the experimental herd. Hence, this unique herd represents a powerful animal model for future fertility research to elucidate the biological mechanisms underpinning differences in fertility without being confounded by milk production.

The superior reproductive performance observed in the Fert+ cows confirms the strong association between genetic merit for fertility traits and the subsequent reproductive performance. In agreement with our findings, Horan et al. (2004) suggested that cows of Holstein or New Zealand Friesian origin that had been selected for superior fertility and survival exhibit superior reproductive performance. Similarly, Coleman et al. (2009) reported differences in pregnancy rate to first service and 6-wk in-calf rate between Holstein cows with a modest $2.46 \mathrm{~d}$ difference in EBV for calving interval (12.24 d difference in the current study) but with similar genetic merit for milk yield. These results confirm the contribution of poor genetic merit for fertility traits to suboptimal fertility performance. Incorporation of fertility traits in national breeding programs can reverse these trends (Norman et al., 2009).

An antagonistic relationship between genetic merit for milk production and fertility has been reported in lactating dairy cows (Pryce et al., 2004; Evans et al., 
Table 3. The effect of genetic merit for fertility traits on reproductive performance during a 20-wk breeding season

\begin{tabular}{|c|c|c|c|c|}
\hline Variable & \multicolumn{2}{|c|}{ Genotype $^{1}$} & $\mathrm{SED}^{2}$ & $P$-value \\
\hline Number of animal records & 18 & 18 & & \\
\hline Calving-to-first service interval (d) & 74.2 & 80.1 & 7.00 & 0.4 \\
\hline Calving-to-conception interval (d) & 85.6 & 113.8 & 10.69 & 0.01 \\
\hline No. of services per cow & 1.78 & 2.83 & 0.51 & 0.05 \\
\hline Conception rate to first service (\%) & 55.6 & 33.3 & - & 0.3 \\
\hline Pregnancy rate to first and second service (\%) & 83.3 & 50 & - & 0.08 \\
\hline 42 -d pregnancy rate $(\%)$ & 72.2 & 41.2 & - & 0.09 \\
\hline Late embryo mortality (\%) & 0 & 11.1 & - & 0.5 \\
\hline Overall pregnancy rate (\%) & 88.9 & 72.2 & - & 0.4 \\
\hline
\end{tabular}

${ }^{1}$ Fert+ = good-fertility cows; Fert- $=$ poor-fertility cows.

${ }^{2} \mathrm{SED}=$ pooled standard error of the difference.

2006a). Cows with high genetic merit for milk yield prioritize the partitioning of nutrients toward milk production, rendering them susceptible to prolonged periods of NEB and BCS loss, resulting in impaired reproductive function (Butler and Smith, 1989). In the current study, genetic merit for milk yield was similar for both groups, but Fert+ cows maintained higher daily milk yield throughout lactation compared with Fert- cow. When daily milk output was expressed as milk solids yield, however, the difference between genotypes was

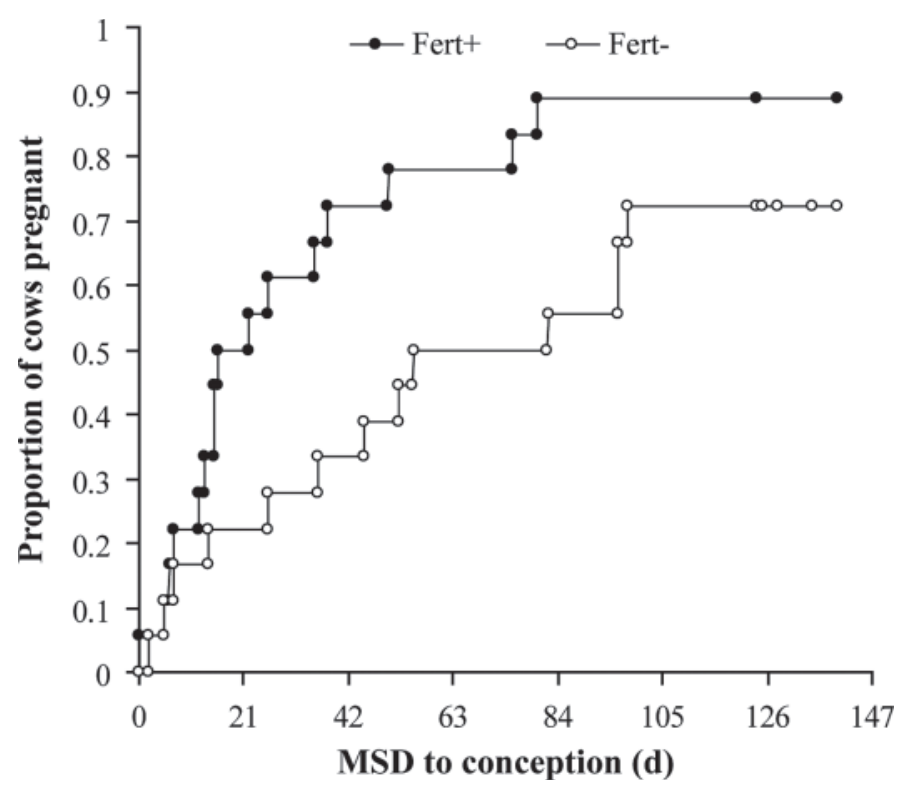

Figure 2. The interval in days from mating start date (MSD) to conception for good-fertility (Fert+) and poor-fertility (Fert-) cows. The $y$-axis represents the proportion of animals pregnant. The Fert+ cows conceived at a significantly greater rate than did the Fert- cows $(P<0.05)$. The median number of days $(95 \% \mathrm{CI}$ in parentheses) for $50 \%$ of the Fert+ cows to conceive was 19 d (13, 38 d), compared with $68.5 \mathrm{~d}(36,98 \mathrm{~d})$ for $50 \%$ of the Fert- cows to conceive. modest. These results suggest that on a grass-based system, Fert+ cows were more capable of expressing their genetic potential for milk yield. This concurs with Buckley et al. (2003), who reported a positive association between phenotypic milk yield and reproductive performance when genetic merit for milk yield and proportion of Holstein genes were included as adjustment variables in the statistical model. However, a lack of consensus exists within the literature on the association between phenotypic milk yield and dairy cow fertility. No association (Patton et al., 2007; LeBlanc, 2010), a negative association (Nebel and McGilliard, 1993; Sakaguchi, 2011), and a positive association (Buckley et al., 2003; Mackey et al., 2007) between phenotypic milk production and measures of reproductive performance have been reported. Despite these seemingly conflicting results, early lactation EB and associated BCS changes have been consistently demonstrated to affect fertility performance (Roche et al., 2009).

Mobilization of body reserves during early lactation is part of an orchestrated series of adaptations in highyielding dairy cows to support mammary milk synthesis (Bauman and Currie, 1980). The severity and duration of NEB during early lactation has been reported to influence fertility (Butler and Smith, 1989). As a subjective visual assessment of adipose tissue reserves, BCS has a strong association with NEB and fertility (Butler, 2003). In the present study, early lactation trends in BCS suggested that Fert+ cows maintained a higher threshold BCS level. This occurred despite maintaining a higher milk yield throughout lactation. The difference in BCS levels seen in early lactation were more pronounced during mid and late lactation, when the Fert+ cows maintained a higher BCS level, indicating superior energy status. These findings concur with Berry et al. (2003), who reported that BCS during mid to late 

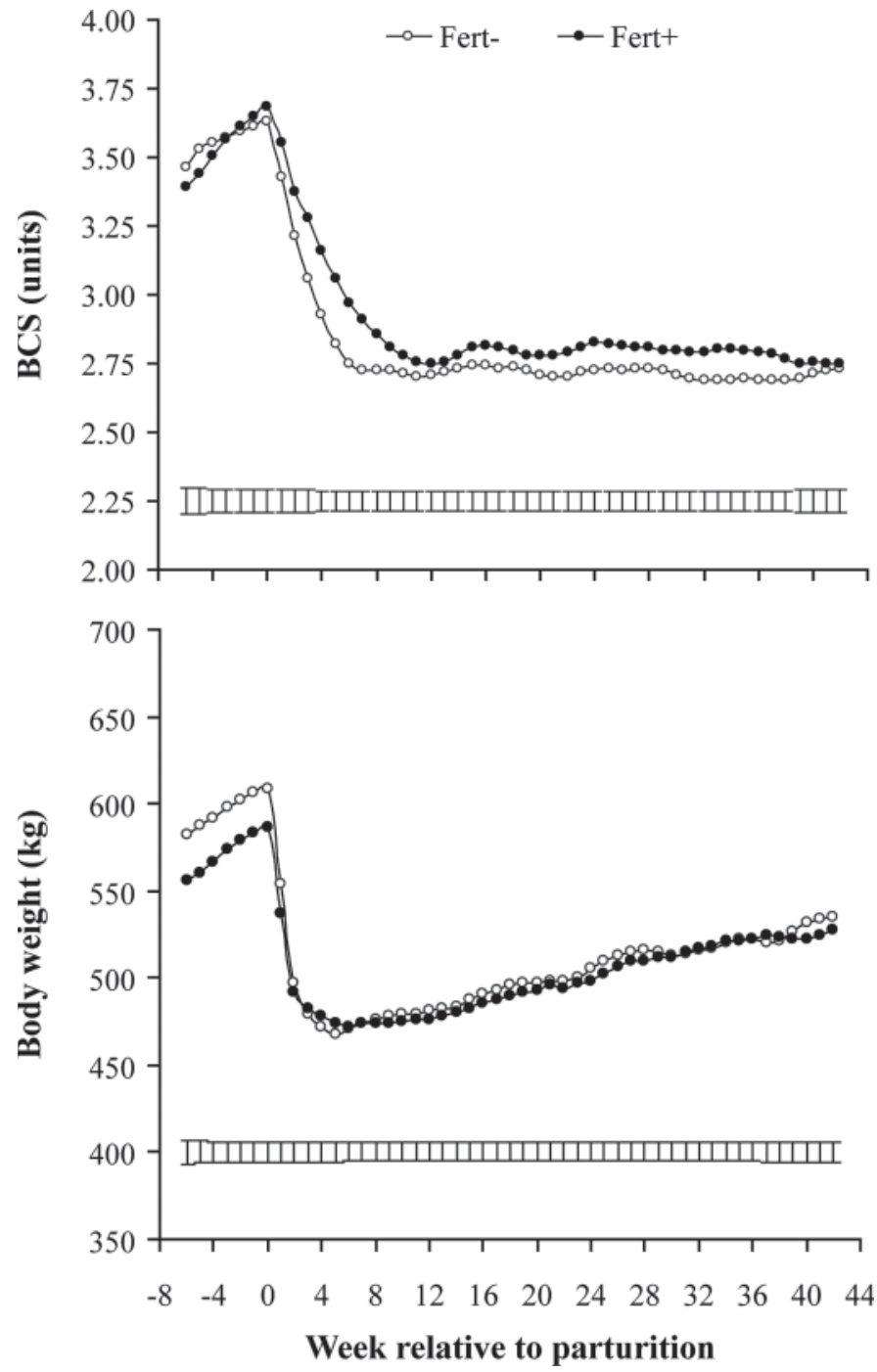

Figure 3. The mean BCS and BW profiles of the good-fertility (Fert+) and poor-fertility (Fert-) cows. Vertical bars indicate the pooled standard error of the difference (SED). Top panel: no genotype effect was observed for mean BCS $(P=0.207$, SED $=0.065$ units $)$ during the gestation-lactation cycle. A significant genotype $\times$ week interaction $(P<0.05)$ for BCS was observed, with the interaction of genotype $\times$ parity tending toward significance $(P=0.072)$. Bottom panel: no genotype, genotype $\times$ week, or genotype $\times$ parity effect was detected for $\mathrm{BW}(\mathrm{SED}=8.96 \mathrm{~kg})$.

lactation had the strongest genetic relationship with fertility. Roche et al. (2006) concluded that cows with a strong genetic drive to produce milk maintained lower BCS throughout lactation. The ability of the Fert+ cows to produce more milk while also maintaining BCS at a higher threshold would suggest that differences in DMI existed. Neither DMI nor calculated EB were different, however, during the 5 measurement periods throughout lactation. The earliest DMI measurement was recorded, on average, 13 wk postpartum (for yr 1 and 2), and perhaps differences in DMI existed before
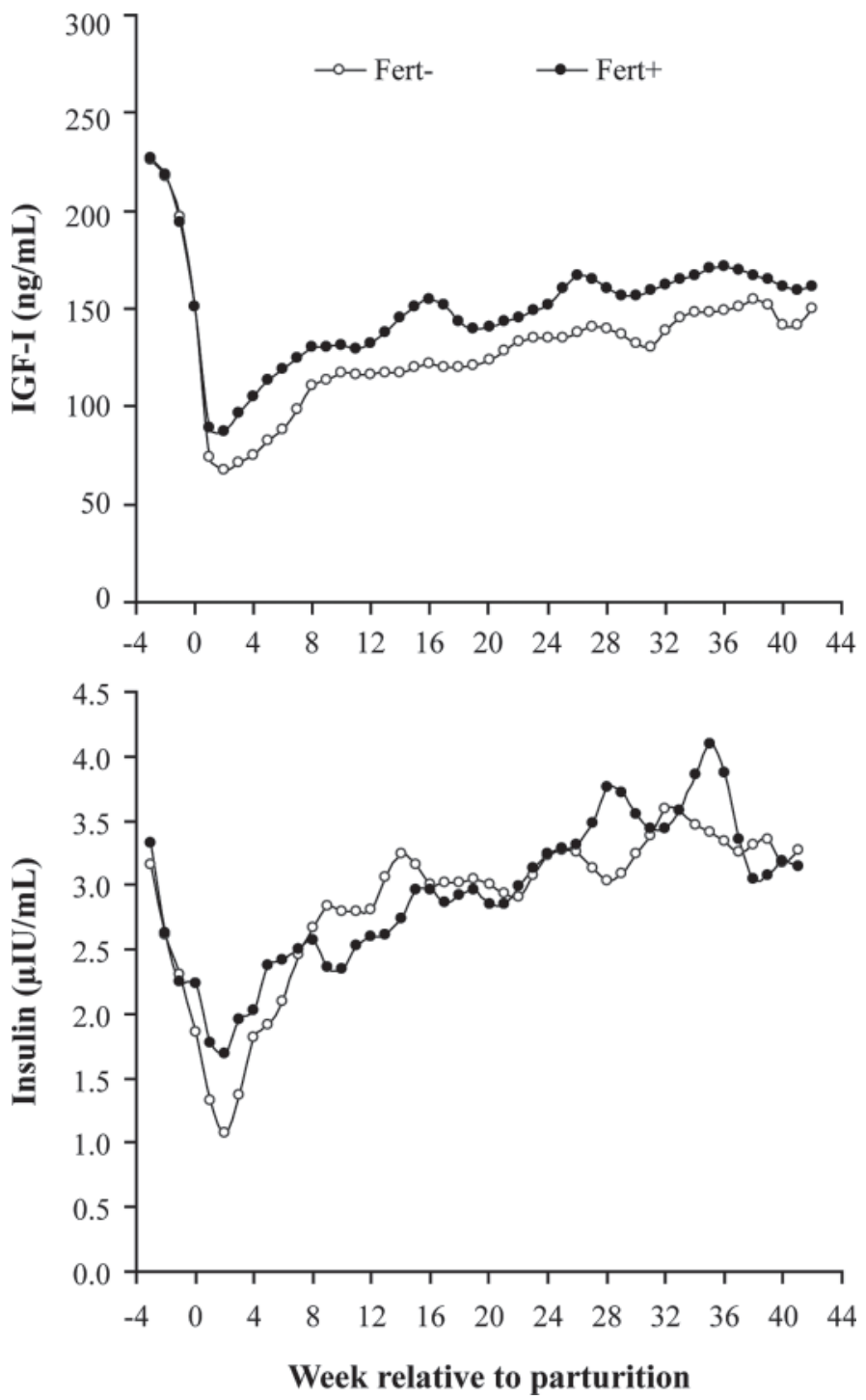

Figure 4. Circulating concentrations of IGF-I and insulin during the gestation-lactation cycle of good-fertility (Fert+) and poor-fertility (Fert-) cows. Top panel: plasma IGF-I concentrations were significantly higher in Fert+ cows $(P<0.01)$ throughout the study period. The mean (95\% CI in parentheses) circulating IGF-I concentrations were $148.3(139.2,157.6)$ and $128.2(119.1,137.7)$ for Fert+ and Fert-, respectively. No genotype $\times$ week or genotype $\times$ parity interactions were observed for IGF-I. Bottom panel: no effect of genotype or genotype $\times$ parity interaction was observed for plasma insulin concentrations $(P>0.05)$. A significant genotype $\times$ week interaction $(P<0.05)$ for insulin was observed during the study period. The mean $(95 \%$ CI in parentheses) circulating insulin concentration were $2.89(2.71,3.07)$ and $2.83(2.64,3.03)$ for Fert+ and Fert-, respectively.

this measurement. Further work to measure daily intakes is required to more closely examine DMI and EB relationships in this animal model.

The link between metabolic status and reproductive efficiency involves the complex integration and regulation of endocrine and metabolic signals (Chagas et al., 2007). Alterations in circulating concentrations of blood 
Table 4. The effect of genetic merit for fertility traits on mean BCS and BW variables

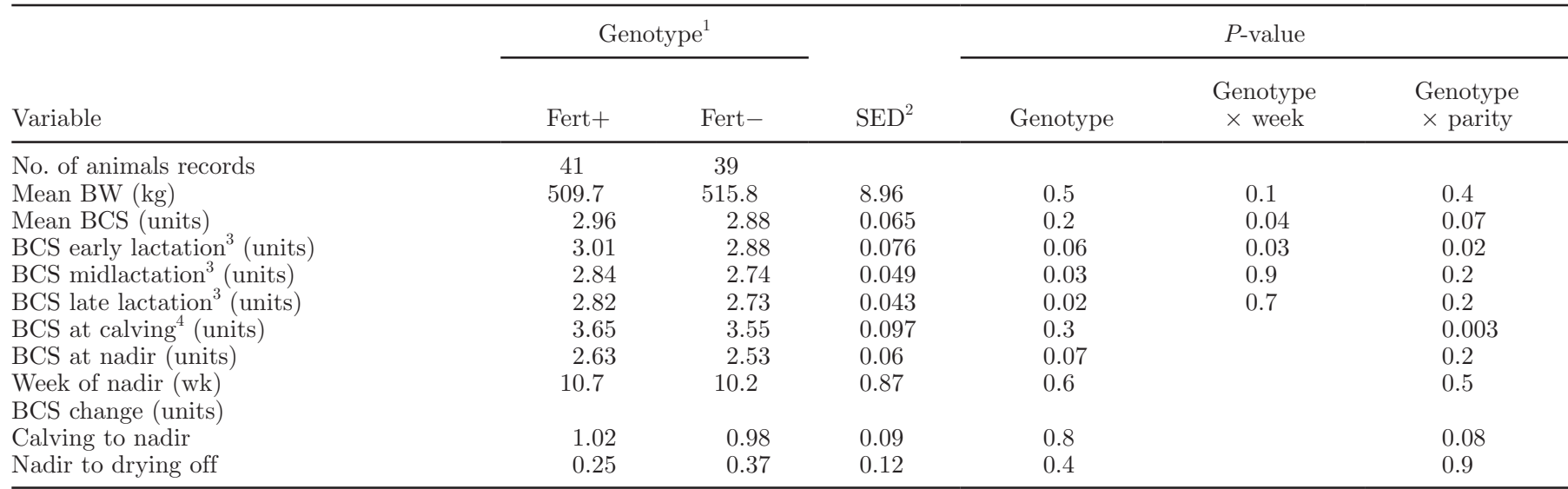

${ }^{1}$ Fert+ = good-fertility cows; Fert- = poor-fertility cows.

${ }^{2} \mathrm{SED}=$ pooled standard error of the difference.

${ }^{3}$ Early lactation $=$ wk 1 to 12 postpartum, midlactation $=$ wk 13 to 28 postpartum, late lactation $=$ wk 29 to 42 .

${ }^{4} \mathrm{BCS}$ at calving was the BCS measured on the week of calving or less than $2 \mathrm{wk}$ before calving.

metabolites and metabolic hormones, such as IGF-I, insulin, glucose, NEFA, and BHBA have been demonstrated to play important roles in the dialog between nutritional status and the reproductive axis (Butler, 2000, 2003; Leroy et al., 2008). In the current study, genetic merit for fertility traits had no effect on circulating concentrations of glucose or NEFA, but plasma concentrations of BHBA were higher during early lactation in Fert+ cows. In support of these findings, Patton et al. (2007) found concentrations of plasma NEFA and glucose measured during the first 4 wk of lactation to have no association with calving to ovulation interval or conception rate. A possible reason for the lack of as- sociation between blood metabolite concentrations and measures of reproductive performance in the current study is that levels of NEFA, BHBA, and glucose were within critical thresholds for healthy cows. Outside these thresholds, the likely development of postpartum metabolic disorders has been shown to have detrimental effects on fertility (Nydam et al., 2009).

The uncoupling of the somatotropic axis in early lactation is a characteristic of high-producing cows and occurs when the liver becomes unresponsive to growth hormone and hepatic IGF-I output is decreased (Lucy, 2001). The observed differences in circulating IGF-I concentrations in the current study indicate a genetic

Table 5. The effect of genetic merit for fertility traits on mean circulating metabolite concentrations ${ }^{1}$

\begin{tabular}{|c|c|c|c|c|c|}
\hline Variable & \multicolumn{2}{|c|}{ Genotype $^{2}$} & \multicolumn{3}{|c|}{$P$-value } \\
\hline NEFA $(\mathrm{mmol} / \mathrm{L})$ & $0.157(0.119,0.206)$ & $0.155(0.119,0.204)$ & 0.9 & 0.8 & 0.07 \\
\hline $\mathrm{BHBA}(\mathrm{mmol} / \mathrm{L})$ & $0.231(0.188,0.281)$ & $0.190(0.154,0.232)$ & 0.2 & 0.9 & 0.06 \\
\hline Glucose $(\mathrm{mmol} / \mathrm{L})$ & $2.84(2.51,3.16)$ & $2.77(2.44,3.10)$ & 0.8 & 0.4 & 0.3 \\
\hline Glucose $(\mathrm{mmol} / \mathrm{L})$ & $2.68(2.49,2.88)$ & $2.65(2.44,2.86)$ & 0.8 & 0.5 & 0.06 \\
\hline \multicolumn{6}{|c|}{ Midlactation (wk 13-28) } \\
\hline NEFA $(\mathrm{mmol} / \mathrm{L})$ & $0.108(0.094,0.124)$ & $0.109(0.094,0.127)$ & 0.9 & 0.9 & 0.08 \\
\hline BHBA (mmol/L) & $0.275(0.243,0.31)$ & $0.247(0.216,0.282)$ & 0.2 & 0.7 & 0.4 \\
\hline Glucose $(\mathrm{mmol} / \mathrm{L})$ & $2.57(2.37,2.77)$ & $2.59(2.37,2.8)$ & 0.9 & 0.7 & 0.1 \\
\hline \multicolumn{6}{|c|}{ Late lactation (wk 29-42) } \\
\hline
\end{tabular}

${ }^{1}$ Geometric mean (95\% CI).

${ }^{2}$ Fert $+=$ good-fertility cows; Fert $-=$ poor-fertility cows. 
Table 6. The effect of genetic merit for fertility traits on milk production and reproductive performance within the Irish national herd during the years 2006 to 2010

\begin{tabular}{|c|c|c|c|c|}
\hline \multirow[b]{2}{*}{ Variable } & \multicolumn{2}{|c|}{ Genotype $^{1}$} & \multirow[b]{2}{*}{$\mathrm{SED}^{2}$} & \multirow[b]{2}{*}{$P$-value } \\
\hline & Fert+ & Fert- & & \\
\hline \multicolumn{5}{|l|}{ Milk production $^{3}$} \\
\hline No. of animal records & 4,859 & 2,371 & & \\
\hline 305 -d milk yield $(\mathrm{kg})$ & 5,556 & 5,503 & 19.3 & 0.007 \\
\hline 305-d protein yield $(\mathrm{kg})$ & 188.8 & 189.2 & 0.61 & 0.5 \\
\hline $305-\mathrm{d}$ fat yield $(\mathrm{kg})$ & 219.4 & 218.3 & 0.75 & 0.1 \\
\hline Protein ( $\mathrm{g} / \mathrm{kg}$ of milk) & 34.1 & 34.5 & 0.01 & $<0.001$ \\
\hline Fat $(\mathrm{g} / \mathrm{kg}$ of milk) & 39.9 & 40.1 & 0.01 & 0.04 \\
\hline Fat-to-protein ratio & 1.17 & 1.16 & 0.003 & 0.003 \\
\hline \multicolumn{5}{|l|}{ Reproductive performance ${ }^{4}$} \\
\hline No. of animal records & 2,436 & 1,388 & & \\
\hline EBV for calving interval ${ }^{5}$ (d) & $-5.6(1.21)$ & $5.2(1.44)$ & & \\
\hline Calving interval (d) & 391.6 & 402.6 & 2.65 & $<0.001$ \\
\hline Recalve within 365 d (\%) & 41 & 33 & 1.6 & $<0.001$ \\
\hline Recalve within 400 d (\%) & 77 & 64 & 1.6 & $<0.001$ \\
\hline
\end{tabular}

${ }^{1}$ Fert $+=$ good-fertility cows; Fert $-=$ poor-fertility cows.

${ }^{2} \mathrm{SED}=$ pooled standard error of the difference.

${ }^{3}$ Milk production data available for 2006 to 2010 inclusive.

${ }^{4}$ Reproductive performance data available for 2006 to 2009 inclusive.

${ }^{5}$ Standard deviation in parentheses.

effect in the regulation of the somatotropic axis. The ability of the Fert+ cows to maintain greater circulating concentrations of IGF-I is consistent with a large body of evidence linking increased IGF-I with improved reproductive outcomes (Taylor et al., 2004). Contrary to previous findings, the observed differences in circulating plasma IGF-I concentrations were independent of alterations in nutrition, Holstein ancestry, milk production, or genetic merit for milk production (Lucy et al., 2009), highlighting for the first time the effect of genetic merit for fertility traits on key components of the somatotropic axis. The precise mechanisms by which Fert+ cows maintained greater concentrations of IGF-I warrant further examination.

Insulin plays a central role in the metabolism of body tissues, acting as an indicator of energy status. In the present study, plasma insulin concentrations were greater for the Fert+ cows during the first 4 wk of lactation. In studies where early postpartum dairy cows were subjected to a hyperinsulinemic-euglycemic clamp infusion, it was shown that elevated circulating insulin concentrations directly affected dominant follicle estradiol output (Butler et al., 2004), and the recoupling of the somatotropic axis through increasing hepatic GHR 1A and IGF-I mRNA expression (Butler et al., 2003). Elevated plasma insulin concentrations as a result of dietary manipulation during the first 50 to 100 d postpartum resulted in shorter intervals from calving to ovulation and from calving to conception, and increased conception rate (Gong et al.,2002). In vitro studies have demonstrated that increased insulin concentrations stimulate granulosa cell proliferation and progesterone steroidogenesis (Spicer and Echternkamp, 1995). The early rise in plasma insulin concentrations observed in Fert+ cows during the immediate postpartum period could be important in the regulation of the somatotropic axis and reproductive events in the postpartum period.

\section{CONCLUSIONS}

Genetic merit for fertility traits had a significant effect on reproductive efficiency in the current study. The Fert+ group had an improved calving-to-conception interval, fewer services, and conceived more quickly after breeding began than did the Fert- group. The observed differences in reproductive performance were independent of management, plane of nutrition, proportion Holstein ancestry, genotypic and phenotypic milk yield, and blood metabolite concentrations of NEFA and glucose. The Fert+ cows maintained greater BCS and circulating concentrations of IGF-I throughout lactation and had greater circulating concentrations of insulin during the first $4 \mathrm{wk}$ of lactation. This supports the premise that animals with superior fertility are less reliant on body reserves for milk synthesis, thus reducing the degree to which the somatotropic axis is uncoupled. These results highlight the effect of genetic merit for fertility on phenotypic reproductive performance, which may not necessarily be to the detriment of milk production.

\section{REFERENCES}

Bauman, D. E., and W. B. Currie. 1980. Partitioning of nutrients during pregnancy and lactation: A review of mechanisms involving homeostasis and homeorhesis. J. Dairy Sci. 63:1514-1529. 
Berry, D. P., F. Buckley, P. Dillon, R. D. Evans, M. Rath, and R. F. Veerkamp. 2003. Genetic parameters for body condition score, body weight, milk yield, and fertility estimated using random regression models. J. Dairy Sci. 86:3704-3717.

Berry, D. P., L. Shalloo, A. R. Cromie, R. F. Veerkamp, P. Dillon, P. R. Amer, J. F. Kearney, R. D. Evans, and B. Wickham. 2007. The economic breeding index: A generation on. Technical report to the Irish Cattle Breeding Federation, Co. Cork, Ireland.

Buckley, F., P. Dillon, M. Rath, and R. F. Veerkamp. 2000. The relationship between genetic merit for yield and live weight, condition score, and energy balance of spring calving Holstein Friesian dairy cows on grass based systems of milk production. J. Dairy Sci. $83: 1878-1886$

Buckley, F., K. O'Sullivan, J. F. Mee, R. D. Evans, and P. Dillon. 2003. Relationships among milk yield, body condition, cow weight, and reproduction in spring-calved Holstein-Friesians. J. Dairy Sci. 86:2308-2319.

Butler, S. T., A. L. Marr, S. H. Pelton, R. P. Radcliff, M. C. Lucy, and W. R. Butler. 2003. Insulin restores GH responsiveness during lactation-induced negative energy balance in dairy cattle: Effects on expression of IGF-I and GH receptor 1A. J. Endocrinol. 176:205-217.

Butler, S. T., S. H. Pelton, and W. R. Butler. 2004. Insulin increases $17 \beta$-estradiol production by the dominant follicle of the first postpartum follicle wave in dairy cows. Reproduction 127:537-545.

Butler, W. R. 2000. Nutritional interactions with reproductive performance in dairy cattle. Anim. Reprod. Sci. 60-61:449-457.

Butler, W. R. 2003. Energy balance relationships with follicular development, ovulation and fertility in postpartum dairy cows. Livest. Prod. Sci. 83:211-218.

Butler, W. R., and R. D. Smith. 1989. Interrelationships between energy balance and postpartum reproductive function in dairy cattle. J. Dairy Sci. 72:767-783.

Chagas, L. M., J. J. Bass, D. Blache, C. R. Burke, J. K. Kay, D. R. Lindsay, M. C. Lucy, G. B. Martin, S. Meier, F. M. Rhodes, J. R. Roche, W. W. Thatcher, and R. Webb. 2007. Invited review: New perspectives on the roles of nutrition and metabolic priorities in the subfertility of high-producing dairy cows. J. Dairy Sci. 90:4022-4032.

Coleman, J., K. M. Pierce, D. P. Berry, A. Brennan, and B. Horan. 2009. The influence of genetic selection and feed system on the reproductive performance of spring-calving dairy cows within future pasture-based production systems. J. Dairy Sci. 92:5258-5269.

Dillon, P., S. Crosse, G. Stakelum, and F. Flynn. 1995. The effect of calving date and stocking rate on the performance of springcalving dairy cows. Grass Forage Sci. 50:286-299.

Dillon, P., and G. Stakelum. 1989. Herbage and dosed alkanes as a grass management technique for dairy cows. Isr. J. Agric. Res. 28:104. (Abstr.)

Edmonson, A. J., I. J. Lean, L. D. Weaver, T. Farver, and G. Webster. 1989. A body condition scoring chart for Holstein dairy cows. J. Dairy Sci. 72:68-78.

Enright, W. J., L. T. Chapin, W. M. Moseley, S. A. Zinn, M. B. Kamdar, L. F. Krabill, and H. A. Tucker. 1989. Effects of infusions of various doses of bovine growth hormone-releasing factor on blood hormones and metabolites in lactating Holstein cows. J. Endocrinol. 122:671-679.

Evans, R. D., P. Dillon, F. Buckle, D. P. Berry, M. Wallace, V. Ducrocq, and D. J. Garrick. 2006a. Trends in milk production, calving rate and survival of cows in 14 Irish dairy herds as a result of the introgression of Holstein-Friesian genes. Anim. Sci. 82:423-433.

Evans, R. D., M. Wallace, L. Shalloo, D. J. Garrick, and P. Dillon. 2006b. Financial implications of recent declines in reproduction and survival of Holstein-Friesian cows in spring-calving Irish dairy herds. Agric. Syst. 89:165-183.

Gong, J. G., W. J. Lee, P. C. Garnsworthy, and R. Webb. 2002. Effect of dietary-induced increases in circulating insulin concentrations during the early postpartum period on reproductive function in dairy cows. Reproduction 123:419-427.

Horan, B., J. F. Mee, P. O'Connor, M. Rath, and P. Dillon. 2004. The effect of strain of Holstein-Friesian cow and feeding system on reproductive performance in seasonal-calving milk production systems. Anim. Sci. 79:453-467.

LeBlanc, S. 2010. Assessing the association of the level of milk production with reproductive performance in dairy cattle. J. Reprod. Dev. 56(Suppl.):S1-S7.

Leroy, J. L. M. R., A. Van Soom, G. Opsomer, and P. E. J. Bols. 2008. The consequences of metabolic changes in high-yielding dairy cows on oocyte and embryo quality. Animal 2:1120-1127.

Lucy, M. C. 2001. Reproductive loss in high-producing dairy cattle: Where will it end? J. Dairy Sci. 84:1277-1293.

Lucy, M. C.. G. A. Verkerk, B. E. Whyte, K. A. Macdonald, L. Burton, R. T. Cursons, J. R. Roche, and C. W. Holmes. 2009. Somatotropic axis components and nutrient partitioning in genetically diverse dairy cows managed under different feed allowances in a pasture system. J. Dairy Sci. 92:526-539.

Mackey, D. R., A. W. Gordon, M. A. McCoy, M. Verner, and C. S. Mayne. 2007. Associations between genetic merit for milk production and animal parameters and the fertility performance of dairy cows. Animal 1:29-43.

Mayes, R. W. C. S. Lamb, and P. M. Colgrove. 1986. The use of dosed and herbage n-alkanes as markers for the determination of herbage intake. J. Agric. Sci. 107:161-170.

McCarthy, S., B. Horan, P. Dillon, P. O'Connor, M. Rath, and L. Shalloo. 2007. Economic comparison of divergent strains of Holstein-Friesian cows in various pasture-based production systems. J. Dairy Sci. 90:1493-1505.

Nebel, R. L., and M. L. McGilliard. 1993. Interactions of high milk yield and reproductive performance in dairy cows. J. Dairy Sci. $76: 3257-3268$

Norman, H. D., J. R. Wright, S. M. Hubbard, R. H. Miller, and J. L. Hutchison. 2009. Reproductive status of Holstein and Jersey cows in the United States. J. Dairy Sci. 92:3517-3528.

Nydam, D. V., P. A. Ospina, T. Stokol, and T. R. Overton. 2009. Evaluation of the effect of non-esterified fatty acids (NEFA) and $\beta$-hydroxybutyrate (BHB) concentrations on health, reproduction and production in transition dairy cattle from the northeast USA. Pages 97-103 in Proc. Cornell Nutrition Conference for Feed Manufacturers 71st Meeting. Department of Animal Science, Cornell University, Ithaca, NY.

Olori, V. E., and P. J. B. Galesloot. 1999. Projection of partial lactation records and calculation of 305-day yields in the Republic of Ireland. Interbull Bull. 22:149-154.

Patton, J., D. A. Kenny, S. McNamara, J. F. Mee, F. P. O'Mara, M. G. Diskin, and J. J. Murphy. 2007. Relationships among milk production, energy balance, plasma analytes, and reproduction in Holstein-Friesian cows. J. Dairy Sci. 90:649-658.

Plaizier, J. C. B., G. J. King, J. C. M. Dekkers, and K. Lissemore. 1997. Estimation of economic values of indices for reproductive performance in dairy herds using computer simulation. J. Dairy Sci. 80:2775-2783.

Pryce, J. E., M. D. Royal, P. C. Garnsworthy, and I. L. Mao. 2004. Fertility in the high-producing dairy cow. Livest. Prod. Sci. $86: 125-135$.

Roche, J. R., D. P. Berry, and E. S. Kolver. 2006. Holstein-Friesian strain and feed effects on milk production, body weight, and body condition score profiles in grazing dairy cows. J. Dairy Sci. 89:3532-3543.

Roche, J. R., N. C. Friggens, J. K. Kay, M. W. Fisher, K. J. Stafford, and D. P. Berry. 2009. Invited review: Body condition score and its association with dairy cow productivity, health, and welfare. J. Dairy Sci. 92:5769-5801.

Royal, M. D., A. O. Darwash, A. P. F. Flint, R. Webb, J. A. Woolliams, and G. E. Lamming. 2000. Declining fertility in dairy cattle: Changes in traditional and endocrine parameters of fertility. Anim. Sci. 70:487-501.

Sakaguchi, M. 2011. Practical aspects of the fertility of dairy cattle. J. Reprod. Dev. 57:17-33.

Spicer, L. J., and S. E. Echternkamp. 1995. The ovarian insulin and insulin-like growth factor system with an emphasis on domestic animals. Domest. Anim. Endocrinol. 12:223-245. 
Taylor, V. J., D. E. Beever, and D. C. Wathes. 2004. Physiological adaptations to milk production that affect the fertility of high yielding dairy cows. Pages 37-71 in Dairying: Using Science to Meet Consumers' Needs. E. Kebreab, J. Mills, and D. Beever, ed. Nottingham University Press, Nottingham, UK.

Veerkamp, R. F., P. Dillon, E. Kelly, A. R. Cromie, and A. F. Groen. 2002. Dairy cattle breeding objectives combining yield, survival and calving interval for pasture-based systems in Ireland under different milk quota scenarios. Livest. Prod. Sci. 76:137-151.
Vermorel, M. 1989. Energy: The feed unit system. Pages 23-32 in Ruminant Nutrition-Recommended Allowances and Feed Tables. R. Jarrige, ed. John Libbey Eurotext, Paris, France.

Washburn, S. P., W. J. Silvia, C. H. Brown, B. T. McDaniel, and A. J. McAllister. 2002. Trends in reproductive performance in southeastern Holstein and Jersey DHI herds. J. Dairy Sci. 85:244-251.

Wilmink, J. B. M. 1987. Adjustment of lactation yield for age at calving in relation to level of production. Livest. Prod. Sci. 16:321334. 